\title{
- PLANOWANIE OPIEKI PIELĘGNIARSKIEJ NAD PACJENTEM GERIATRYCZNYM PO ZABIEGU ENDOPROTEZOPLASTYKI PRZEBYWAJACYM W ŚRODOWISKU DOMOWYM - STUDIUM PRZYPADKU
}

\section{PLANNING NURSING CARE OF THE GERIATRIC PATIENT AFTER ENDOPROTHESOPLASTIC SURGERY WHO LIVES IN A HOME ENVIRONMENT - CASE STUDY}

\author{
Lucyna Monika Sochocka, Edyta Kędra, Patryk Gawlik
}

Wydział Pielęgniarstwa, Państwowa Medyczna Wyższa Szkoła Zawodowa w Opolu

DOI: https://doi.org/10.20883/pielpol.2018.15

\section{STRESZCZENIE}

Założenia. Celem pracy jest zaprezentowanie przykładowego planu opieki pielęgniarskiej nad przebywającym w środowisku domowym pacjentem geriatrycznym po zabiegu endoprotezoplastyki. Proponowany plan opieki oparty został na klasyfikacji ICNP, będącej międzynarodowym standardem dla terminologii pielęgniarstwa, rekomendowanym przez ICN, a w Polsce przez PTP oraz Akredytowane Centrum Badania i Rozwoju ICNP®. Klasyfikacja ta porządkuje terminologię specjalistyczną poprzez stworzenie słownika referencyjnego terminów wykorzystywanych do stawiania diagnozy pielęgniarskiej, planowania działań i oceniania wyników, którym przypisane są odpowiednie kody numeryczne. Dzięki temu staje się ona uniwersalnym narzędziem do porozumiewania się pielęgniarek na całym świecie i do zapewniania odpowiedniej jakości tej opieki.

Prezentacja przypadku. J.S., lat 94, po zabiegu endoprotezoplastyki eliptycznej połowiczej stawu biodrowego prawego wykonanym z powodu złamania szyjki kości udowej. Po leczeniu na oddziale chirurgii urazowo-ortopedycznej wypisana w stanie dobrym do domu z zaleceniem przyjmowania leków oraz rehabilitacji. Opiekę nad Panią J.S. sprawują członkowie najbliższej rodziny, pielęgniarka opieki długoterminowej oraz fizjoterapeuta. Według skali Katza (ADL) pacjentkę charakteryzuje się jako znacznie niesprawną; ocena wg skali Lawtona (IADL) wskazuje na stan określany jako umiarkowanie zależny.

Wyniki. U pacjentów w wieku geriatrycznym upadki są poważnym problemem społecznym z uwagi na ich powszechność i częstość powikłań. Opiekępielęgniarskąnad pacjentemnależyzaplanować, opierając się na analizie dostępnej dokumentacji medycznej, wnikliwej obserwacji stanu zdrowia i potrzeb pacjenta oraz wywiadzie z podopiecznym i członkami najbliższej rodziny. Zgodnie z obowiązującymi standardami opieka ta to zindywidualizowany proces pielęgnowania przygotowany z wykorzystaniem klasyfikacji ICNP stanowiącej uniwersalny język komunikacji między personelem pielęgniarskim na całym świecie; proces ten pozwala na zapewnienie ciągłości opieki i wysokiej jej jakości.

SŁOWA KLUCZOWE: złamanie, endoprotezoplastyka, pacjent geriatryczny, proces pielęgnowania.

\begin{abstract}
Assumptions. The aim of the research is to present an exemplary plan of the geriatric patient care after endoprothesoplastic surgery in home environment. The proposed care plan is based on the classification of the ICNP, which is the international standard for nursing terminology, recommended by the ICN, and in Poland by the PTP and the Accredited Center for Research and Development of the ICNP®. This classification organizes specialized terminology, by creating a reference dictionary of terms used in the diagnosis of nursing, action planning and performance evaluation, which are assigned to the corresponding numeric codes. As a result, it becomes a universal tool to communicate with nurses around the world and to provide adequate quality of care.

Presentation of the case. J.S., a 94-year-old woman, after endoprosthetics with partial hip replacement made due to the hip fracture. After having been treated at the Trauma and Ortopaedic Surgery Ward, the patient was discharged from the hospital in a good condition. She was prescribed with pharmacotherapy and rehabilitation. The family members, district nurse and physical therapist have been taking care of Mrs J.S. The Katz's Index (ADL) signifies the patient as very dependent; according to Lawton's Scale (IADL) the patient is mildly dependent.

Conclusions. Falls in older adults are a significant social problem due to their commonness and frequency of complications. Nursing care of the patient should be planned by making a right diagnosis based on analysis of the available medical documentation, careful observation of patient's condition and his/her needs, as well as interviewing his/her immediate family. According to the current standards, it is based on the individualized process of nurturing prepared using the ICNP classification which constitutes a universal language of communication between the nursing staff around the world, allowing to provide continuity of care and high quality.
\end{abstract}

KEYWORDS: fracture, endoprothesoplastic surgery, geriatric patient, nursing care. 


\section{Wprowadzenie}

U osób w podeszłym wieku złamania szyjki kości udowej są powszechnymi uszkodzeniami układu ruchu. Stanowią poważne zagrożenie życia z powodu powikłań, do których dochodzi często wskutek trwałego unieruchomienia pacjentów w łóżku. Złamania bliższego końca kości udowej wynikają z osłabienia siły mięśniowej, zrzeszotnienia kości, zmniejszenia sprawności fizycznej oraz z postępujących zmian miażdżycowych naczyń krwionośnych mózgu. Do objawów świadczących o złamaniu zalicza się przede wszystkim zgłaszany przez pacjenta ból w okolicy biodra i pachwiny; chory nie jest w stanie ustać o własnych siłach, choć przy złamaniach zaklinowanych często możliwe jest chodzenie. Złamana kończyna ustawia się w rotacji zewnętrznej i przywiedzeniu, w przypadku znacznych przemieszczeń kończyna może ulec skróceniu [1].

Obecnie standardem w leczeniu złamań szyjki kości udowej jest zastosowanie endoprotezy połowiczej bipolarnej. Metoda ta polega na umocowaniu w kości udowej cementowego lub bezcementowego trzpienia, na którym następnie osadzana jest głowa. Łączy się ona z drugą, nieco większą głową, wprowadzaną do panewki własnej pacjenta. Ten typ endoprotezy powinno stosować się w złamaniach osteoporotycznych szyjki kości udowej u starszych pacjentów [2].

Wskazania do wykonania endoprotezoplastyki stawu biodrowego to $\mathrm{m}$.in. niepoddająca się leczeniu zachowawczemu choroba zwyrodnieniowa stawu biodrowego wraz z towarzyszącymi jej dolegliwościami bólowymi, ograniczeniem ruchomości oraz przykurczami, a także złamania szyjki kości udowej wymagające nagłej interwencji.

Przeciwwskazaniami do zastosowania tej metody leczenia są: zakażenia stawu oraz skóry w najbliższej okolicy planowanego zabiegu, artropatia neurogenna, znaczna osteoporoza, zaburzenia zakrzepowo-zatorowe, schorzenia ogólnoustrojowe, znaczna otyłość, a także młody wiek [3].

Pielęgniarska opieka długoterminowa jest świadczona osobom, które nie kwalifikują się do leczenia szpitalnego, a ich stan zdrowia wymaga systematycznej i zwiększonej opieki pielęgniarskiej [4]. Sprawowanie czynności pielęgnacyjnych nad pacjentem powinno odbywać się zgodnie z etapami procesu pielęgnowania, dlatego podjęcie opieki należy rozpocząć od zgromadzenia danych na temat podopiecznego oraz postawienia diagnozy pielęgniarskiej.

Na podstawie diagnozy rodziny i społeczności lokalnej pielęgniarka opieki długoterminowej jest w stanie wskazać możliwości włączenia systemu wsparcia społecznego, który można podzielić na pierwotny i wtór- ny. Pierwotny system wsparcia społecznego to najbliższe osoby z otoczenia pacjenta: sąsiedzi, dalsza rodzina, przyjaciele i znajomi. Wtórny system wsparcia społecznego, zwany również instytucjonalnym, to grupy udzielające samopomocy oraz instytucje świadczące pomoc osobom znajdującym się w trudnych sytuacjach życiowych [4].

Celem pracy jest zaprezentowanie przykładowego planu opieki nad przebywającym w środowisku domowym pacjentem geriatrycznym po zabiegu endoprotezoplastyki. W tworzeniu planu wykorzystano międzynarodowy standard ICNP (ang. International Classification Nursing Practice). Jest to klasyfikacja rekomendowana przez ICN, do praktycznego zastosowania w pielęgniarstwie światowym, oparta na ujednoliconej klasyfikacji nazewnictwa wraz z przypisanymi im kodami dla poszczególnych etapów procesu pielęgnowania, który jest procesem 3-etapowym (diagnoza pielęgniarska, działania, wyniki) [5].

W pracy wykorzystano metode indywidualnego przypadku; dominującą techniką była technika analizy dokumentacji, pozwalająca na przygotowanie opisu przypadku. W ramach wiodącej metody zastosowano również technikę wywiadu, pozwalającą doprecyzować zebrane informacje na potrzeby przygotowywanego opisu. Równolegle skorzystano również z metody obserwacji $[6,7]$.

\section{Opis przypadku}

J.S., lat 94, po zabiegu endoprotezoplastyki eliptycznej połowiczej stawu biodrowego prawego wykonanym z powodu złamania szyjki kości udowej. Złamanie było skutkiem upadku, do którego doszło w mieszkaniu chorej, w godzinach nocnych, w drodze do toalety. Po 15 dniach pobytu na oddziale chirurgii urazowo-ortopedycznej Pani J.S. została wypisana do domu z zaleceniem usunięcia szwów chirurgicznych oraz kontroli w poradni urazowo-ortopedycznej. Ponadto zalecono przyjmowanie leków: Clexane 40 1x1 s.c. oraz Proxacin $2502 \times 1$ p.o. Kobiecie wystawiono także skierowanie do szpitala na oddział rehabilitacji oraz zlecenie dalszej rehabilitacji w domu polegającej na wykonywaniu ćwiczeń usprawniających staw biodrowy prawy oraz na nauce chodzenia z wykorzystaniem balkonika z pełnym obciążeniem operowanej kończyny.

Od 10 lat (od śmierci męża) kobieta samotnie zamieszkuje parterowy dom jednorodzinny. W sąsiedztwie J.S. mieszka jej syn wraz z rodziną, który codziennie odwiedza matkę. Częstym gościem Pani J. jest również jej córka. Syn z żoną oraz córka kobiety wyrazili gotowość włączenia się do opieki po powrocie J.S. ze szpitala. W sprawowaniu opieki nad Panią J. pomagają także pielęgniarka opieki długoterminowej Diecezjalnej Stacji Opieki Caritas oraz fizjoterapeuta. 
J.S. ma 167 cm wzrostu, waży 60 kg. Na podstawie obserwacji stwierdzić można widoczny obrzęk okolicy podudzia kończyny operowanej; skóra jest sucha, w okolicy kości krzyżowej, stawu skokowego prawego oraz obu pięt wyraźnie zaczerwieniona. Okolica rany pooperacyjnej sucha, czysta, bez oznak stanu zapalnego.

Pani J. nie potrafi samodzielnie wstać z łóżka, korzysta z wózka inwalidzkiego, na którym jest w stanie poruszać się po mieszkaniu, nie potrafi jednak samodzielnie przemieszczać się z łóżka na wózek. Kobieta ma do swojej dyspozycji balkonik, z którego korzysta niechętnie. Za jego pomocą jest w stanie przejść kilka metrów, czynność ta wymaga jednak asysty. Pani J. nie wyraziła zgody na pobyt na oddziale rehabilitacji pobliskiego szpitala, argumentując swoją decyzję chęcią rehabilitacji w domu. J.S. korzysta z pieluchomajtek z powodu przygodnego nietrzymania moczu i stolca. Syn kobiety przyznaje, że pieluchomajtki są zanieczyszczone najczęściej w godzinach rannych. Kobieta nie potrafi samodzielnie korzystać z toalety; wymaga pomocy przy wykonywaniu toalety całego ciała. Posiłki spożywa samodzielnie, są one jednak wcześniej przygotowywane przez któregoś z członków rodziny. Pani J. samodzielnie gospodaruje pieniędzmi, potrafi korzystać z telefonu. Kobieta pamięta o przyjmowaniu leków, nie potrafi jednak samodzielnie ich przygotować. Pani J. nie została wyedukowana w zakresie podawania iniekcji podskórnych leku przeciwzakrzepowego. Zabieg ten wykonywany jest zazwyczaj przez pielęgniarkę opieki długoterminowej.

Pani J. jest zorientowana co do miejsca, czasu i własnej osoby, zachowuje kontakt logiczny z otoczeniem. J.S. mówi półszeptem, rzadko się uśmiecha. Jest wyraźnie niezadowolona ze swej obecnej sytuacji życiowej. Skarży się na fakt okresowego nietrzymania moczu i stolca oraz uzależnienia od innych podczas zaspokajania podstawowych potrzeb. Jest zaniepokojona brakiem możliwości swobodnego przemieszczania się po swoim domu. Przyznaje, że z powodu dolegliwości bólowych kończyny operowanej i w obawie przed ponownym upadkiem niechętnie korzysta z balkonika. Więcej czasu w ciągu dnia spędza w łóżku z założonymi barierkami, co skutkuje problemami ze snem w nocy. Pani J. często prowadzi rozważania nad śmiercią i umieraniem.

Według skali Katza (ADL) pacjentkę charakteryzuje się jako znacznie niesprawną (suma pkt 1), zależną w następujących czynnościach: samodzielne kąpanie się, ubieranie, korzystanie z toalety, przemieszczanie się oraz kontrolowanie wydalania moczu i stolca [8]. Ocena wg skali Lawtona (IADL) - 11 pkt - pozwala natomiast określić stan pacjentki jako umiarkowanie zależny: w zakresie gospodarowania pieniędzmi, korzystania z telefonu, przygotowywania i przyjmowania leków Pani J. wymaga niewielkiej pomocy. Przemieszczać się na większe odległości, wychodzić na zakupy po artykuły spożywcze, przygotować sobie posiłki, wykonywać prace domowe (np. sprzątanie), majsterkować i wyprać swoje rzeczy - tych czynności kobieta nie jest w stanie wykonać samodzielnie. W zakresie żadnej z ww. czynności kobieta nie jest całkowicie niezależna [9].

Tabela 1. Ocena podstawowych czynności dnia codziennego wg skali ADL Table 1. Evaluation of daily living basic activities according to $A D L$ scale

\begin{tabular}{cc}
\hline Czynności/Actions & $\begin{array}{c}\text { Samodzielność } \\
\text { pacjenta/ } \\
\text { Patient's inde- } \\
\text { pendence }\end{array}$ \\
\hline Kąpanie się/Bathing & 0 \\
\hline Ubieranie i rozbieranie się/Dressing and undressing & 0 \\
Korzystanie z toalety/Using the toilet & 0 \\
$\begin{array}{c}\text { Wstawanie z tóżka i przemieszczanie się na fotel/Getting up } \\
\text { out of bed and moving on the chair }\end{array}$ & 0 \\
\hline $\begin{array}{c}\text { Samodzielne jedzenie//Independent eating } \\
\text { Kontrolowanie wydalanie moczu i stolca/Controlling the } \\
\text { excretion of urine and stool }\end{array}$ & 1 \\
\hline Suma punktów/Total points & 0 \\
\hline
\end{tabular}

Źródło: opracowanie własne

Source: author's own analysis

Tabela 2. Ocena złożonych czynności życia codziennego wg skali IADL Table 2. Evaluation of daily living complex activities by IADL scale

\begin{tabular}{|c|c|}
\hline Czynności/Actions & $\begin{array}{l}\text { Liczba punk- } \\
\text { tów/Number } \\
\text { of points }\end{array}$ \\
\hline $\begin{array}{c}\text { Czy potrafisz korzystać z telefonu:/Can you use the phone: } \\
3 \text { - bez pomocy/without help } \\
2-\text { z niewielką pomocą/with a little help } \\
1 \text { - zupełnie nie jesteś w stanie/you cannot }\end{array}$ & 2 \\
\hline $\begin{array}{c}\text { Czy jesteś w stanie przemieszczać się na większe odległości:/ } \\
\text { Are you able to move over greater distances: } \\
3 \text { - bez pomocy/without help } \\
2 \text { - z niewielką pomocą/with a little help } \\
1 \text { - zupełnie nie jesteś w stanie/you cannot }\end{array}$ & 1 \\
\hline $\begin{array}{c}\text { Czy wychodzisz na zakupy po artykuły spożywcze:/Do you go } \\
\text { out shopping for groceries: } \\
3 \text { - bez pomocy/without help } \\
2 \text { - z niewielką pomocą/with a little help } \\
1 \text { - zupełnie nie jesteś w stanie robić jakichkolwiek zakupów/ } \\
\text { you are not able to do any shopping at all }\end{array}$ & 1 \\
\hline $\begin{array}{c}\text { Czy możesz samodzielnie przygotować sobie posiłki:/Can you } \\
\text { prepare your meals: } \\
3 \text { - bez pomocy/without help } \\
2-\text { z niewielką pomocą/with a little help } \\
1 \text { - nie jesteś w stanie/you cannot }\end{array}$ & 1 \\
\hline $\begin{array}{c}\text { Czy możesz samodzielnie wykonywać prace domowe (np. } \\
\text { sprzątanie:)/Can you carry out the chores (eg. cleaning): } \\
3 \text { - bez pomocy/without help } \\
2 \text { - z niewielką pomocą/with a little help } \\
1 \text { - zupełnie nie jesteś w stanie/you cannot }\end{array}$ & 1 \\
\hline $\begin{array}{c}\text { Czy możesz samodzielnie majsterkować i wyprać swoje rze- } \\
\text { czy:/Can you tinker yourself and wash your stuff: } \\
3 \text { - bez pomocy/without help } \\
2 \text { - z niewielką pomocą/with a little help } \\
1 \text { - nie jesteś w stanie/you cannot }\end{array}$ & 1 \\
\hline
\end{tabular}




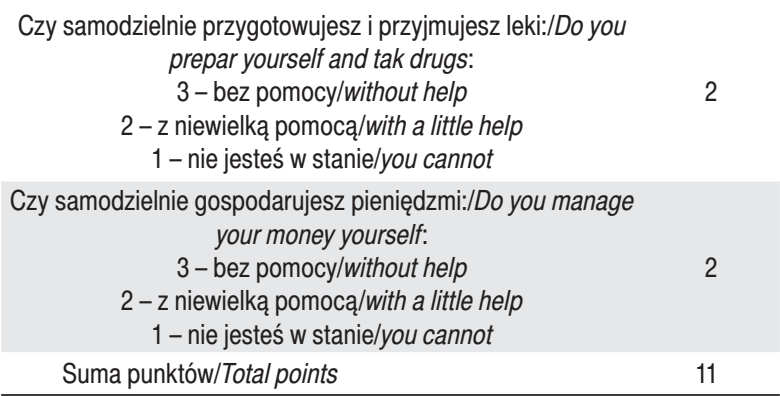

Źródło: opracowanie własne

Source: author's own analysis

\section{Plan opieki pielęgniarskiej}

z zastosowaniem Międzynarodowej Klasyfikacji Praktyki Pielęgniarskiej (ICNP)

Diagnoza pielęgniarska: zaburzona zdolność przemieszczania [10001005] osoby starszej [10006604].

Przedmiot: zdolność do przemieszczania się [10000204] - zdolność: poruszanie się i zmiana położenia ciała np. między jedną a drugą lokalizacją.

Interwencje:

- ewaluacja stanu domu przed rozpoczęciem opieki domowej [10041038] w trakcie wizyty domowej [10009082] przez pielęgniarkę [10013156] i dokumentowanie [10006173];

- ocenianie zdolności chodzenia [10038917] dokonywana przez pielęgniarkę [10013156] i dokumentowanie [10006173];

- ocenianie możliwości [10026040] rodziny [10007554] przez pielęgniarkę [10013156] i dokumentowanie [10006173];

- ocenianie gotowości do uczenia się [10002781] osoby starszej [10006604] i rodziny [10007554] dokonywane przez pielęgniarkę [10013156];

- ocenianie wiedzy [10033882] dokonywane przez fizjoterapeutę [10024003] i pielęgniarkę [10013156];

- nauczanie o technikach przemieszczania się [10041489] z zastosowaniem materiału instruktażowego [10010395] ukierunkowane na osobę starszą [10006604] i rodzinę [10007554] prowadzone przez pielęgniarkę [10013156] i fizjoterapeutę [10024003];

- nauczanie o technice chodzenia [10037461] przez fizjoterapeutę [10024003] i pielęgniarkę [10013156];

- ocenianie reakcji na nauczanie [10024279] dokonywane przez fizjoterapeutę [10024003] i pielęgniarkę [10013156];

- wzmacnianie osiągnięć [10026427] osoby starszej [10006604] i rodziny [10007554];
- promowanie zdolności do samodzielnego przemieszczania się [10041157] osoby starszej [10006604] przez fizjoterapeute [10024003] i pielęgniarkę [10013156];

- transportowanie pacjenta [10020095] przez pielęgniarkę [10013156] i rodzinę [10007554] za pomocą urządzenia do transportu [10020082] z zapewnieniem dostępu do środków transportu [10041306];

- ocenianie ryzyka urazu podczas transportu [10030723] dokonywane przez pielęgniarkę [10013156] i dokumentowanie [10006173].

Diagnoza wynikowa: efektywna zdolność przemieszczania się [10028322].

Diagnoza pielęgniarska: ryzyko upadku [10015122] osoby starszej [10006604].

Przedmiot: upadek [10007512] - zdarzenie lub epizod.

Interwencje:

- ocenianie zdolności chodzenia [10038917] dokonywana przez pielęgniarkę [10013156] i dokumentowanie [10006173];

- monitorowanie ryzyka upadku [10037442] dokonywane przez pielęgniarkę [10013156] z zastosowaniem skali oceny bezpieczeństwa (upadek [10007512]) i dokumentowanie [10006173];

- ocenianie [10002673] wiedzy o środkach bezpieczeństwa [10021973] osoby starszej [10006604] i rodziny [10007554] przez fizjoterapeutę [10024003] i pielęgniarkę [10013156];

- zapewnienie urządzenia zabezpieczającego [10024527] dla osoby starszej [10006604] przez fizjoterapeutę [10024003] i pielęgniarkę [10013156];

- zastosowanie urządzenia zabezpieczającego [10002472] przez osobę starszą [10006604];

- asystowanie w chodzeniu z wykorzystaniem urządzenia [10036520] przez fizjoterapeutę [10024003] i pielęgniarkę [10013156];

- wzmacnianie umiejętności [10026188] nabytych przez osobę starszą [10006604] i rodzinę [10007554] dokonywane przez fizjoterapeute [10024003] i pielęgniarkę [10013156];

- promowanie chodzenia z wykorzystaniem urządzenia [10037636] dokonywane przez fizjoterapeutę [10024003] i pielęgniarkę [10013156].

Diagnoza wynikowa: bez upadku [10034704].

Diagnoza pielęgniarska: brak wiedzy o prewencji upadków [10040230] u osoby starszej [10006604] i rodziny [10007554]. 
Przedmiot: wiedza o prewencji upadków [10039779] - wiedza.

\section{Interwencje:}

- ocenianie [10002673] wiedzy o prewencji upadków [10039779] dokonywane przez pielęgniarkę [10013156];

- ocenianie możliwości [10026040] dokonywane przez pielęgniarkę [10013156] i fizjoterapeutę [10024003];

- ocenianie gotowości do uczenia się [10002781] dokonywane przez pielęgniarkę [10013156];

- nauczanie profilaktyki upadków [10023406] prowadzone przez pielęgniarkę [10013156] i fizjoterapeutę [10024003] z dostarczaniem materiału instruktażowego [10024493];

- nauczanie opiekuna[10033086] prewencji upadków [10040187] przez pielęgniarkę [10013156] i fizjoterapeutę [10024003];

- nauczanie pacjenta [10033126] prewencji upadków [10040187] przez pielęgniarkę [10013156] i fizjoterapeutę [10024003];

- demonstrowanie prewencji upadków [100224710] przez pielęgniarkę [10013156] i fizjoterapeutę [10024003];

- dostarczenie wytycznych nt. zapobiegania [10026375] przez pielęgniarkę [10013156] i fizjoterapeutę [10024003];

- ocenianie reakcji na nauczanie [10024279] dokonywane przez pielęgniarkę [10013156] i fizjoterapeutę [10024003] oraz jej dokumentowanie [10006173];

- wzmacnianie osiągnięć [10026427] osoby starszej [10006604] i rodziny [10007554] dokonywane przez pielęgniarkę [10013156] i fizjoterapeutę [10024003];

- wzmacnianie umiejętności [10026188] osoby starszej [10006604] i rodziny [10007554] dokonywane przez pielęgniarkę [10013156] i fizjoterapeutę [10024003].

Diagnoza wynikowa: wiedza adekwatna [10027112].

Diagnoza pielęgniarska: ryzyko nietolerancji aktywności [10015011] przez osobę starszą [10006604].

Przedmiot: nietolerancja aktywności ruchowej [10000408] - zaburzony status: brak zdolności lub energii do kontynuowania lub zakończenia działań.

\section{Interwencje:}

- ocenianie tolerancji aktywności ruchowej [10037945] dokonywane przez fizjoterapeutę [10024003] i pielęgniarkę [10013156] oraz dokumentowanie [10006173];
- ocenianie możliwości [10026040] osoby starszej [10006604] dokonywane przez fizjoterapeutę [10024003] i pielęgniarkę [10013156] i dokumentowanie [10006173];

- monitorowanie tolerancji aktywności ruchowej [10036622] dokonywane przez fizjoterapeutę [10024003] i pielęgniarkę [10013156] oraz dokumentowanie [10006173];

- ocenianie gotowości do uczenia się [10002781] osoby starszej [10006604] i rodziny [10007554] dokonywane przez pielęgniarkę [10013156];

- nauczanie o sposobie zwiększania tolerancji aktywności ruchowej [10024660] kierowane do rodziny [10007554] i prowadzone przez fizjoterapeutę [10024003] i pielęgniarkę [10013156];

- nauczanie o ćwiczeniach [10024602] prowadzone przez fizjoterapeutę [10024003] i pielęgniarkę [10013156];

- nauczanie o rehabilitacji [10033017] kierowane do osoby starszej [10006604] i rodziny [10007554] prowadzone przez fizjoterapeutę [10024003];

- nauczanie o ćwiczeniach [10040125] osoby starszej [10006604] i rodziny [10007554] prowadzone przez fizjoterapeutę [10024003] i pielęgniarkę [10013156];

- dostarczanie materiału instruktażowego [10024493] i materiału dydaktycznego [10011251] przez fizjoterapeutę [10024003] i pielęgniarkę [10013156];

- ocenianie reakcji na nauczanie [10024279] osoby starszej [10006604] i rodziny [10007554] dokonywane przez fizjoterapeute [10024003] i pielęgniarkę [10013156];

- ocenianie wiedzy [10033882] osoby starszej [10006604] i rodziny [10007554] dokonywane przez fizjoterapeutę [10024003] i pielęgniarkę [10013156];

- wzmacnianie osiągnięć [10026427] osoby starszej [10006604] i rodziny [10007554] dokonywane przez fizjoterapeutę [10024003] i pielęgniarkę [10013156];

- wzmacnianie umiejętności [10026188] osoby starszej [10006604] i rodziny [10007554] dokonywane przez fizjoterapeutę [10024003] i pielęgniarkę [10013156];

- zarządzanie reżimem ćwiczeń [10023890] osoby starszej [10006604] dokonywane przez fizjoterapeutę [10024003] i pielęgniarkę [10013156].

Diagnoza wynikowa: tolerancja aktywności ruchowej [10024878].

Diagnoza pielęgniarska: ryzyko odleżyny [10027337] u osoby starszej [10006604]. 
Przedmiot: odleżyna [10015612] - wrzód: uszkodzenie, stan zapalny oraz bolesność skóry lub tkanki podskórnej, wywołana uciskiem na tkanki i niedostatecznym ukrwieniem.

\section{Interwencje:}

- ocenianie ryzyka odleżyny [10030710] przez pielęgniarkę [10013156] z zastosowaniem skali oceny bezpieczeństwa (odleżyna [10015612]) i jej dokumentowanie [10006173];

- prewencja odleżyn [10040224] z zastosowaniem materaca przeciwodleżynowego [10041560] i środków pomocniczych [10019157] u osoby starszej [10006604];

- uruchamianie [10012120] osoby starszej [10006604] przez zastosowanie urządzenia uruchamiającego [10012131] z zastosowaniem wiedzy o środkach bezpieczeństwa [10021973];

- $\quad$ higiena [10009285] osoby starszej [10006604] oraz zdolność do wykonywania czynności higienicznych [10000184] i samodzielnego utrzymywania higieny [10017769] przez osobę starszą [10006604];

- ocenianie [10002673] wzorca higieny [10009292] u osoby starszej [10006604] i rodziny [10007554] przez pielęgniarkę [10013156];

- ocenianie [10002673] mycia się [10017846] i wzorca higieny [10009292] u osoby starszej [10006604];

- $\quad$ pielęgnacja skóry [10032757] osoby starszej [10006604] poprzez względną ocenę stanu [10026750] dokonywaną przez pielęgniarkę [10013156];

- ocenianie skóry [10041126] przez pielęgniarkę [10013156] i dokumentowanie [10006173];

- ocenianie gotowości do uczenia się [10002781] rodziny [10007554] dokonywane przez pielęgniarkę [10013156];

- ocenianie możliwości [10026040] rodziny [10007554] przez pielęgniarkę [10013156] i dokumentowanie [10006173];

- nauczanie o prewencji odleżyn [10036861] rodziny [10007554] przez pielęgniarkę [10013156] z zastosowaniem materiału dydaktycznego [10011251] i wiedzy o pielęgnowaniu rany [10011026];

- dostarczanie materiału instruktażowego [10024493] imateriału dydaktycznego[10011251] przez pielęgniarkę [10013156];

- ocenianie reakcji na nauczanie [10024279] rodziny [10007554] dokonywane przez pielęgniarkę [10013156] i dokumentowanie [10006173];

- ocenianie wiedzy [10033882] rodziny [10007554] przez pielęgniarkę [10013156];
- wzmacnianie osiągnięć [10026427] rodziny [10007554] przez pielęgniarkę [10013156];

- wzmacnianie umiejętności [10026188] rodziny [10007554] przez pielęgniarkę [10013156].

Diagnoza wynikowa: bez odleżyny [10029065].

Diagnoza pielęgniarska: zaburzona zdolność do wykonywania czynności higienicznych [10000987] przez osobę starszą [10006604].

Przedmiot: zdolność do wykonywania czynności higienicznych [10000184] - zdolność: dbałość o utrzymanie estetycznego wyglądu i czystości ciała.

Interwencje:

- ewaluacja stanu domu przed rozpoczęciem opieki domowej [10041038] w trakcie wizyty domowej [10009082] przez pielęgniarkę [10013156] i dokumentowanie [10006173];

- ocenianie możliwości [10026040] przez pielęgniarkę [10013156] poprzez względną ocenę stanu [10026750];

- asystowanie przy czynnościach higienicznych [10023531] osoby starszej [10006604] zgodnie z wzorcem higieny [10009292] przez rodzinę [10007554] i pielęgniarkę [10013156];

- asystowanie w toalecie [10023531] osobie starszej [10006604] przez rodzinę [10007554] i pielęgniarkę [10013156];

- mycie [10020935] osoby starszej [10006604] zgodnie z wzorcem higieny [10009292] przez rodzinę [10007554] i pielęgniarkę [10013156];

- czesanie [10004640] osoby starszej [10006604] przez rodzinę [10007554] i pielęgniarkę [10013156];

- dbanie o estetyczny wygląd [10008528] osoby starszej [10006604] przez rodzinę [10007554] i pielęgniarkę [10013156];

- $\quad$ promowanie higieny [10032477] osoby starszej [10006604] przez pielęgniarkę [10013156];

- pielęgnacja jamy ustnej [10032184] zgodnie z wzorcem higieny jamy ustnej [10032204] przez rodzinę [10007554] i pielęgniarkę [10013156];

- pielęgnacja skóry [10032757] zgodnie z wzorcem higieny jamy ustnej [10032204] przez rodzinę [10007554] i pielęgniarkę [10013156];

- dostarczanie materiału instruktażowego [10024493] przez pielęgniarkę [10013156];

- $\quad$ ocenianie gotowości do uczenia się [10002781] osoby starszej [10006604] i rodziny [10007554] przez pielęgniarkę [10013156];

- nauczanie rodziny o wzorcu utrzymywania higieny [10038131] z wykorzystaniem materiałów dydaktycznych [10011251] przez pielęgniarkę [10013156]; 
- ocenianie reakcji na nauczanie [10024279] osoby starszej [10006604] i rodziny [10007554] przez pielęgniarkę [10013156];

- ocenianie wiedzy [10033882] osoby starszej [10006604] i rodziny [10007554] przez pielęgniarkę [10013156];

- wzmacnianie osiągnięć [10026427] osoby starszej [10006604] i rodziny [10007554] przez pielęgniarkę [10013156];

- wzmacnianie umiejętności [10026188] osoby starszej [10006604] i rodziny [10007554] przez pielęgniarkę [10013156].

Diagnoza wynikowa: zaburzona zdolność do wykonywania czynności higienicznych [10000987].

Diagnoza pielęgniarska: strach przed byciem ciężarem dla innych [10041671] ze strony osoby starszej [10006604].

Przedmiot: strach przed byciem ciężarem dla innych [10026594].

Interwencje:

- ocenianie strachu przed byciem ciężarem dla innych [10026254] przez pielęgniarkę [10013156];

- poradnictwo dotyczące strachu [10026208] przez pielęgniarkę [10013156];

- zapewnienie wsparcia duchowego [10027067] osobie starszej [10006604] adekwatnie do względnej oceny stanu [10026750] w postaci usługi religijnej [10016737];

- zapewnienie wsparcia emocjonalnego [10027051] przez rodzinę [10007554] i pielęgniarkę [10013156];

- $\quad$ zapewnienie wsparcia społecznego [10027046] przez dalszą rodzinę [10007410] i społeczność [10004733];

- promowanie wsparcia rodziny [10036078] przez pielęgniarkę [10013156] i społeczność [10004733];

- promowanie poczucia własnej wartości [10024455] u osoby starszej [10006604] przez rodzinę [10007554] i pielęgniarkę [10013156];

- $\quad$ ułatwianie możliwości wypełniania roli [10026277] członka rodziny [10007596] osobie starszej [10006604] przez rodzinę [10007554] i pielęgniarkę [10013156];

- promowanie samoopieki [10026347] u osoby starszej [10006604] przez pielęgniarkę [10013156] i rodzinę [10007554].

Diagnoza wynikowa: zmniejszający się strach [10027889].

Diagnoza pielęgniarska: ryzyko negatywnej jakości życia [10040945] osoby starszej [10006604].

Przedmiot: jakość życia [10040643] - status.

\section{Interwencje:}

- ocenianie jakości życia [10040658] osoby starszej [10006604] przez pielęgniarkę [10013156] za pomocą skal funkcjonalnych (ADL i IADL) i dokumentowanie [10006173];

- dostarczenie wsparcia duchowego [10027067] osobie starszej [10006604] adekwatnie do względnej oceny stanu [10026750] w postaci usługi religijnej [10016737];

- dostarczenie wsparcia emocjonalnego [10027051] osoby starszej [10006604] i rodzinie [10007554] adekwatnie do względnej oceny stanu [10026750] przez pielęgniarkę [10013156];

- dostarczenie wsparcia społecznego [10027046] przez społeczność lokalną [10004733], dalszą rodzinę [10007410] adekwatnie do względnej oceny stanu [10026750] przez pielęgniarkę [10013156];

- ocenianie wiedzy [10033882] osoby starszej [10006604] i rodziny [10007554] przez pielęgniarkę [10013156] i pracownika socjalnego [10024088] na temat roli pracownika socjalnego [10018468] i usługi pracownika socjalnego [10018475];

- nauczanie rodziny o pomocy społecznej [10036130] przez pracownika socjalnego [10024088].

Diagnoza wynikowa: pozytywna diagnoza i wynik [10016479].

\section{Dyskusja}

Przeprowadzenie zabiegu endoprotezowania jest jednym ze sposobów leczenia złamań szyjki kości udowej, do których dochodzi często wskutek upadków osób starszych.

Zdaniem Maciejuk-Płońskiej [10] złamania szyjki kości udowej niosą za sobą konsekwencje psychologiczne i społeczne. Osoby doświadczające urazu tracą swą niezależność, trudno jest im odnaleźć się w nowej rzeczywistości, często charakteryzują się obniżonym nastrojem i podwyższonym poziomem lęku. Podobne problemy wystąpiły u chorej będącej podmiotem studium przypadku prezentowanego w pracy. Lęk przed wystąpieniem ponownego upadku i obniżony nastrój spowodowany sytuacją życiową chorej były czynnikami ryzyka w procesie jej usprawniania. By nie opóźnić procesu rekonwalescencji, zastosowano szereg interwencji pielęgniarskich, mających na celu zmniejszenie lęku oraz poprawę nastroju.

Puzio i wsp. [9] podają, że przeprowadzenie zabiegu endoprotezoplastyki niesie ze sobą konsekwencje w postaci czasowego ograniczenia w wykonywaniu 
czynności dnia codziennego. W pierwszym miesiącu po zabiegu pacjenci mają największe problemy w zakresie kontrolowania moczu i stolca, a także w wykonywaniu takiej czynności jak kąpanie się. Właśnie dlatego należy zwracać szczególną uwagę na konieczność włączania reedukacji podstawowych i złożonych czynności dnia codziennego do programu usprawniania chorych po zabiegu endoprotezoplastyki.

\section{Wnioski}

Szczegółowa analiza przytoczonego powyżej opisu przypadku pozwala autorom stwierdzić, iż:

- u pacjentów w wieku geriatrycznym upadki są poważnym problemem społecznym z uwagi na ich powszechność i częstość powikłań;

- $\quad$ złamania szyjki kości udowej, jako jedno z powikłań upadków, znacznie upośledzają funkcjonowanie osób starszych;

- okres do miesiąca od przeprowadzenia zabiegu endoprotezoplastyki stawu biodrowego niesie za sobą szereg problemów natury fizycznej i psychicznej u pacjentów w wieku geriatrycznym;

- opiekę pielęgniarską nad pacjentem należy zaplanować poprzez sformułowanie odpowiednich diagnoz pielęgniarskich, opierając się na analizie dostępnej dokumentacji medycznej, wnikliwej obserwacji stanu zdrowia i potrzeb pacjenta oraz wywiadzie z podopiecznym i członkami najbliższej rodziny;

- $\quad$ w opiece pooperacyjnej nad pacjentem w środowisku domowym należy podjąć działania mające na celu zapobieganie wystąpieniu powikłań pooperacyjnych, niwelowanie zaistniałych problemów natury fizycznej i psychicznej oraz przygotowanie do samoopieki;

- $\quad$ przygotowanie do samoopieki obejmuje edukację podopiecznych i członków najbliższej rodziny w zakresie zachowań zdrowotnych mających na celu utrzymanie zdrowia i szybki powrót do aktywności życiowej.

\section{Piśmiennictwo}

1. Słowiński K. Złamania kości. W: Noszczyk W (red.). Chirurgia. T. 1. Warszawa: PZWL; 2005. 5-12.
2. Pozowski A. Alloplastyka stawu biodrowego. Wrocław: Górnicki Wydawnictwo Medyczne; 2011. 13-19.

3. Bączyk G, Kapała W. Podstawy kliniczne oraz pielęgnowanie chorych w okresie przed- i pooperacyjnym w chirurgii ogólnej, ortopedii i traumatologii. Poznań: Wydawnictwo Naukowe Uniwersytetu Medycznego im. Karola Marcinkowskiego w Poznaniu; 2012. 37-49.

4. Kędziora-Kornatowska K, Muszalik M, Skolmowska E. Pielęgniarstwo w opiece długoterminowej. Warszawa: PZWL; 2015. 46-48.

5. Kilańska D. Międzynarodowa Klasyfikacja Praktyki Pielęgniarskiej (ICNP) - aktualny stan na świecie i etap prac przygotowawczych do wdrożenia w Polsce. Probl Piel. 2009; 17(3): 235-245.

6. Lenartowicz H, Kózka M. Metodologia badań w pielęgniarstwie. Warszawa: PZWL; 2010. 34-41.

7. Lesińska-Sawicka M. Metoda Case Study w pielęgniarstwie. Warszawa: Borgis Wydawnictwo Medyczne; 2009. 23-29.

8. Borowiak E, Kostka T. Analiza sprawności funkcjonalnej osoby w starszym wieku. Rola pielęgniarki w zespole terapeutycznym. W: Wieczorowska-Tobis K, Talarska D (red.). Geriatria i pielęgniarstwo geriatryczne. Warszawa: PZWL; 2014. 99-115.

9. Puzio G, Stopa A, Szczygielska-Babiuch A et al. Ocena podstawowych i złożonych czynności życia codziennego pacjentów geriatrycznych po zabiegu endoprotezoplastyki stawu biodrowego. Post Rehabil. 2014; 28(4): 13-20.

10. Maciejuk-Płońska A, Nasiłowska-Barud A, Kostecka P et al. Psychologiczne aspekty rehabilitacji osób starszych po złamaniu szyjki kości udowej. Pol Merk Lek. 2012; 32(187): 79-81.

Artykuł przyjęty do redakcji: 12.01 .2017

Artykuł przyjęty do publikacji: 09.06.2017

Źródło finansowania: Praca nie jest finansowana z żadnego źródła. Konflikt interesów: Autorzy deklarują brak konfliktu interesów.

\author{
Adres do korespondencji: \\ Lucyna Sochocka \\ ul. Katowicka 68 \\ 45-060 Opole \\ tel.: 774423540 \\ e-mail: I-sochocka@wp.pl \\ Wydział Pielęgniarstwa \\ Państwowa Medyczna Wyższa Szkoła Zawodowa w Opolu
}

